\title{
Equine Infectious Anemia-Research in Japan on the Virology, Immunology, Pathogenesis and Control
}

\author{
Hideo NAKAJIMA and Takeo SUGIURA
}

Epizootic Research Station, Equine Research Institute, The Japan Racing Association, 1400-4, Shiba, Kokubunji-chou, Shimotsuga-gun, Tochigi-ken 329-04, Japan

\section{Contents}

J. Equine. Sci.

Vol. 5, No. 1

pp 1-19

\begin{tabular}{|c|c|}
\hline & Introdu \\
\hline & Cultivation of the Virus \\
\hline & 1. Horse Cells \\
\hline & 2. Cells other than Horse Cells \\
\hline & 3. Horse Leukocyte Culture \\
\hline & Characteristics of EIA Virus \\
\hline & 1. Morphological Properties \\
\hline & 2. Physicochemical Properties \\
\hline & 3. Biological Properties .......... \\
\hline & 4. Classification ............................. \\
\hline \multirow[t]{5}{*}{ IV. } & Immunology \\
\hline & 1. Hypergammaglobulinemia .................. \\
\hline & 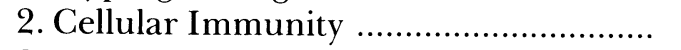 \\
\hline & 3. Immunosuppression ............................. \\
\hline & 4. Auto-Immunity ......... \\
\hline
\end{tabular}

\section{Introduction}

Equine infectious anemia (EIA) is an acute, subacute, or chronic infectious disease of only equidae. It is characterized by recurrent fever, anemia, and lifelong persistent infection with the etiological virus. It induces marked changes in the lymphoid, reticuloendothelial, and perivascular tissues. Proliferation of basophilic round cells or small lymphoid cells and activation (proliferation) of reticuloendothelial cells are characteristic of these changes. Once horses are infected with EIA virus, they show recurrent high fever ranging from 40 to $42^{\circ} \mathrm{C}$, severe anemia, reduction or loss of vigor and appetite, and other symptoms. Some of them die, and others survive to retain the virus
V. Pathogenesis .................................. 8

1. Recurrence and Persistence ............. 8

2. Anemia .......................................... 9

VI. Diagnosis ................................... 9

1. Serological Diagnosis ....................... 9

2. Immunodiffusion Test .................... 10

VII. Prevention ..................................... 14

1. Control in Japan ............................ 14

2. Protection .................................... 14

VIII. Conclusion .................................... 15

IX. References..................................... 15

through life in the body and become a source of infection to other healthy horses. Such being the case, it is a very important problem in the equine industry to control this disease. Strenuous efforts have been made in many countries for a long time. Even at present, however, it is impossible to develop a vaccine on account of the complicated diversity of EIA virus, and the prevention of this disease remains yet unattainable. Therefore, for the control of EIA in the present situation, there is no other method than to make an accurate diagnosis of the disease in order to condemn an infected horse acting as a source of infection.

In 1904, Vallée and Carré reported that the etiological agent of EIA is a filterable virus [114]. During several decades after that, however, 
studies of the causative agent were delayed in comparison to those of other fields such as clinical medicine, hematology, pathology or epizootiology. This is because EIA virus is not infective to any experimental animal other than equine genus and cultured cells.

In 1961, Kobayashi reported that EIA virus could be propagated in equine bone-marrow cells and leukocytes cultured in vitro [22-24]. This is the most epoch-making result ever been obtained in the history of EIA research. In particular, it was demonstrated that the quantitative determination of EIA virus was possible in vitro, with the cytopathic effect (CPE) of the propagating virus as an indicator, by using leukocytes which had been obtained from the jugular vein of a healthy horse and cultured in bovine serum. Studies of EIA virus had long been stagnant stage while they had been relying only on horses. Since the horse leukocyte culture method was developed, great progress has been made in studies on virology, immunology, pathogenesis and diagnosis of the disease, and they have reached the same level as those of other animal viruses, though slowly [20, 59].

As a result of studies conducted for the past several decades, physical, biochemical, morphological, biological, and immunological properties of EIA virus have been considerably elucidated. It has also been made possible to make an accurate diagnosis of EIA on the basis of the antigen-antibody reaction with the virus antigen $[53,54,61$, 75]. Of these findings, it should be noted that EIA virus has physicochemical and morphological properties quite similar to those of RNA tumor viruses and taxonomically belongs to the Retroviridae family $[8,52,55]$. It should also be noted particularly that while EIA virus was proliferated in the body of the horse, it underwent a consecutive variation into antigenically different viruses which were distinguishable from one another by the neutralization test, and, as a result, persistent infection with EIA virus was established, and that recurrent fever was induced in infected horses by the occurrence of viremia of the variant viruses $[28,30,38]$.

The pathogenesis of EIA which includes uncommon characteristics and complicated features as described above was clarified during 1970 and 1975.

At present, EIA virus is classified in the genus of Lentivirus with viruses of Visna/Maedi, caprine arthritis/encephalomyelitis, and acquired immuno-deficiency syndrome (AIDS), the last of which has become particularly serious problem in human beings since 1981. It should be especially emphasized that the same propagation mode as that of the etiological virus of AIDS had already been identified in EIA virus more than twenty years ago in Japan.

The present paper describes advances in research performed mainly in Japan for the past several decades on cultivation of the virus, characteristics of the virus, immunology including serology, pathogenesis, diagnosis and prevention of EIA.

\section{Cultivation of the Virus}

Difficulty in cultivating EIA virus was a major reason why analysis of the virus, immunity and the EIA disease had not progressed. Development of the horse leukocyte culture for cultivation and titration of the virus by Kobayashi contributed to the development of a method for serological diagnosis and to other virological and biological research [22-26], especially demonstration of the antigenic drift of the virus [38]. The establishment of a continuously infected culture system of equine dermal cell line by Malmquist also made a great contribution to the preparation of a large amount of the virus [43].

\section{Horse Cells}

Kobayashi observed that EIA virus propagated in horse bone-marrow cell culture and leukocyte culture, and was accompanied by a CPE [22-24]. This virus was readily subjected to passage in these cell cultures. A culture showing CPE always included the infectious virus to horses. It is considered that these cells are macrophages, because cultured cells which adhere to the glass of culture tubes are spherical in shape and unable to multiply. The virus multiplying in the bone marrow cell culture reached a level of $10^{6} \mathrm{TCID}_{50} / \mathrm{ml}$, as well as that in horse leukocyte culture [41].

The virus also propagated in fibroblast-like cells, such as cultured bone-marrow and kidney cells, but not in spleen cells [40].

A strain of virus adapted to the leukocyte culture can multiply in epithelioid or fibroblastlike cells originating in the kidney and bone 
marrow [40]. This point is to be discussed in a succeeding chapter.

\section{Cells other than Horse Cells}

Macrophages in the peritoneal cavity and kidney cells of guinea pigs, hamsters, mice, and rabbits are not susceptible to the virus. Also, the virus did not multiply in chick embryo cells, BHK-21 cells, HeLa cells, or KB cells [40].

It has been reported that EIA virus could multiply in Wi-38, cell line of human lung origin [95], in bone-marrow cells of guinea pigs [42], and in cells of cats [3]. These results, however, have not been confirmed as yet.

An equine dermal cell line (NBL-6) persistently infected with EIA virus was developed by Malmquist $e t$ al. [43]. It is easy to get a large amount of the virus by means of this system. Recently Bouillant $e$ al. reported that the virus can multiply in the Cf2Th, canine thymus cell line [4]. In this persistently infected cell line, the virus can be demonstrated for 100 serial passages. It is considered that the equine dermal cell line is the best culture with which to get a large amount of the virus, although we can get only the virus material of Wyoming strain which was adapted to horse leukocyte culture. On the other hand, the horse leukocyte culture is suitable to titrate the virus infectivity and to isolate a large number of the virus strains, although there is the risk that equine herpes virus (EHV) will contaminate the culture.

\section{Horse Leukocyte Culture}

Horse leukocyte culture is routinely used for propagation of the virus for virological research, production of antigen for sero-diagnosis, titration of the virus, and other purposes.

It is not always easy to prepare a satisfactory horse leukocyte culture for titration or propagation of EIA virus without fail. Preparing a suitable serum for culture medium from bovine and a donor horse free from EHV-2 for leukocytes are essential for successful cultivation.

1) Methods

The method which is carried out by the authors is shown in Fig. 1. It is desirable for all the processes to be done at low temperature. Special attention should be paid to the velocity and time of centrifugation. It is also necessary to resuspend the cell sediment without delay.

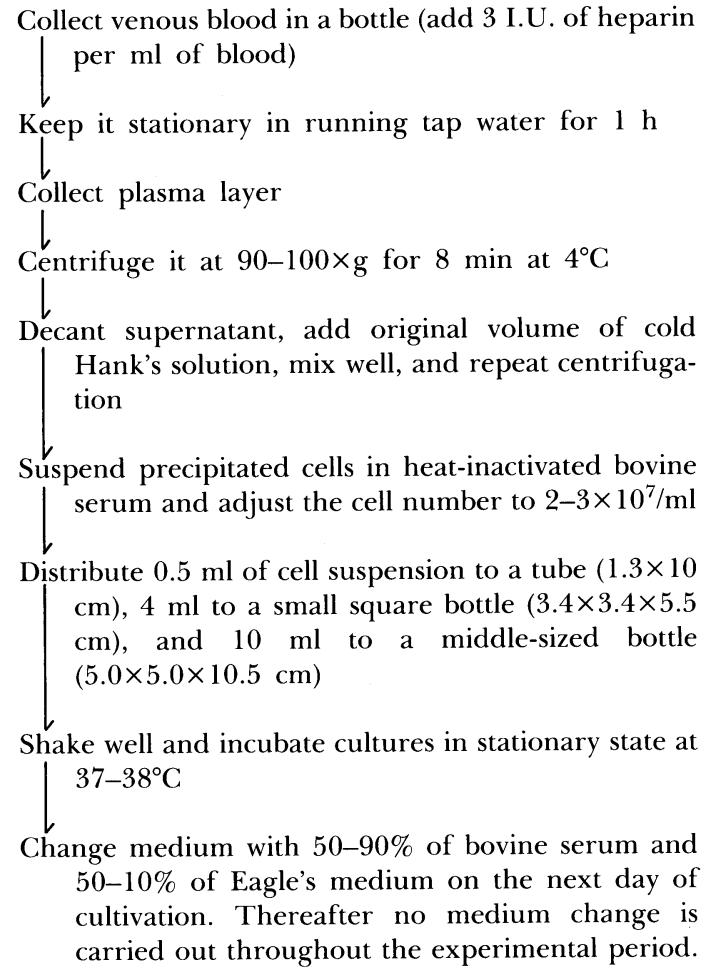

Fig. 1. A method designed for preparation of horse leukocyte cultures

2) Factors Influencing Cultivation

Selection of donor horses is the most important factor in obtaining good cultures. Once an excellent donor is found, satisfactory leukocyte cultures can be expected with almost every cultivation. Definitive factors for the donor horse are unknown. At least, however, the rate of constitution of blood cells or the age difference between donor horses is not closely related to the result of the leukocyte culture [25].

The concentration of leukocytes at the beginning of cultivation is also a very important factor. 2 to $7 \times 10^{7}$ cells $/ \mathrm{ml}$ is the suitable number for the culture [23].

The composition of the culture medium is also an important factor. It is necessary to contain at least $50 \%$ of bovine serum in order to maintain the cells in a satisfactory condition for more than 3 weeks. The most satisfactory results will be obtained when the bovine serum itself is used as the culture medium. Good results will not be obtained even if the serum of a donor horse is used as the culture medium (Kono, unpublished data). In general, one serum sample suitable for leukocytes from an individual horse can also be a 
good medium for cultures from other donor horses. About 30 to $40 \%$ of horses and 10 to $20 \%$ of cows provide satisfactory cultures (unpublished data).

Attention must always be paid to contamination by means of the herpes virus which persistently infects donor horses for leukocyte culture. Kono and Kobayashi clearly showed that almost all the horses showed latent infection with EHV-2 [32, 33]. And also there is a possibility of persistent infection with EHV-1 and -4. These viruses are hardly present in serum and are commonly associated with leukocytes. The propagation of these viruses in the culture can be inhibited by adding heat inactivated serum from the same donor horse at the rate of 5 to $10 \%$ of the culture fluid.

\section{Characteristics of EIA Virus}

\section{Morphological Properties}

The purified virus specimen obtained from infected horse leukocyte cultures was studied by electron microscopy to clarify morphological features of EIA virus [68]. Viral particles showed considerable pleomorphism although most of them were spherical with diameters between 90 and $140 \mathrm{~nm}$ (Fig. 2a). The particle appeared to be covered with fine projections. Virions seemed to be easily damaged and spontaneous disruption was frequent. In such disrupted particles, an outer envelope approximately $9 \mathrm{~nm}$ thick was made visible presumably by penetration of the stain to the interior. No internal structural detail was, however, defined. Some particles showed the "tail" which was often observed in RNA tumor viruses. Similar particles were seen in the material from the infected horse serum [76]. The presence of the same particles was also demonstrated by Tajima $e t$ $a l$. in membrane-bound cytoplasmic vesicles, extracellular spaces and on the surface of infected culture cells (Fig. 2 b, c) [106]. The particles had a spherical shape and were between from 80 and $120 \mathrm{~nm}$ in diameter. They had a single limiting membrane, and an electron-dense nucleoid 40-60 $\mathrm{nm}$ in diameter, viroplasma and presumably surface projections. In some particles, the inner particle shell could be seen around the nucleoid. They were observed to form by a process of budding from the plasma membrane of cultured cells (Fig. 2c). The particles described were not detected in uninfected cultured cells and their appearance could be prevented by adding EIA immune serum to the inoculum.

\section{Physicochemical Properties}

Studies using ${ }^{3} \mathrm{H}$-uridine showed conclusively that EIA virus has RNA as its nucleic acid core [57, 72]. The viral RNA sediments at a rate of approximately $70 \mathrm{~S}$ which is similar in size to that of RNA tumor viruses [5, 59]. The propagation of EIA virus was, however, inhibited by 5-iododeoxyuridine (IUDR) during the early phase of the infectious cycle, and the addition of thymidine to the culture reversed the inhibitory effect of IUDR [41]. As a result, it was considered that DNA is involved in the virus replication. In addition, the presence of RNA dependent DNA polymerase which utilized synthetic template-primer, poly $(\mathrm{rA})$ oligo (dT) was demonstrated in the virion $[56,66]$. This therefore strongly suggested that the virus genome RNA was strongly transcribed to DNA in infected cells, and that the DNA may have been integrated into the host genome as shown in RNA tumor viruses.

The virus consists of more than 10 structural proteins with a major protein band having an apparent molecular weight (MW) of 25,000 dalton [5, 79]. This is regarded as one of the groupspecific proteins of EIA virus and acts as an antigen in immunodiffusion reaction.

Using purified EIA virus labeled with ${ }^{3} \mathrm{H}$ glucosamine or ${ }^{14} \mathrm{C}$ protein hydrolysate, structural proteins were analyzed by sodium dodecyl sulfatepolyacrylamide gel electrophoresis [79]. As a result, 2 glycoproteins and 10 proteins with a MW ranging from 12,000 to 115,000 daltons were demonstrated. Of 12 structural proteins, 3 proteins, namely a glycoprotein with MW of 76,000 (gp76) and 2 proteins with MW of 25,000 (p25) and 12,000 (p12), respectively, had antigenic activity distinct from one another in immunodiffusion. Development of antibodies against gp76 and p25 was compared in infected horses. The antibody to gp76 appeared earlier and stronger than that to p25 in horses infected with the homologous virus strain.

The fraction with glycoproteins was found to have hemagglutinating activity which was inhibited by the serum sample from horses infected with EIA virus.

The density of EIA virus particles is 1.15 to 1.16 



Fig. 2. (a) Equine infectious anemia virus (EIAV) purified and negative stained with $2 \%$ phosphotungstic acid $(\times 210,000)$. (b) EIAV observed in infected cultured horse leukocytes $(\times 56,000)$. (c) Release of EIAV by budding from infected cell surface $(\times 140,000)$.

$\mathrm{g} / \mathrm{cm}^{3}[52,69,70,79]$. The sedimentation constant is approximately $650 \mathrm{~S}$ [44]. The virus resists against ultraviolet irradiation [63]. It is also resistant to trypsin [71]. On the other hand, EIA virus in the serum from infected horses and infected cultured fluids was completely inactivated after treatment with ether for 5 min $[52,65]$.

Stability of EIA virus was studied at $\mathrm{pH}$ levels between 2.5 and 12.0 by incubating the virus material for $10 \mathrm{~min}$ to $48 \mathrm{~h}$ [31]. The result indicates that $\mathrm{EIA}$ virus was not inactivated at a $\mathrm{pH}$ ranging from 6.0 to 9.0 for $5 \mathrm{~h}$ but it was 
completely inactivated at $\mathrm{pH} 3.0$ and 11.0 within 1 $\mathrm{h}$. The virus partially lost its infectivity $5 \mathrm{~h}$ after treatment at $\mathrm{pH} 5.0$, although it was not affected at all $1 \mathrm{~h}$ after treatment at the same $\mathrm{pH}$ value.

The virus in infected horse serum was very stable at low temperatures and could be stored at $-20^{\circ} \mathrm{C}$ for 7 years without marked loss of infectivity to horses. At $38^{\circ} \mathrm{C}$ the infectivity of the virus material decreased by about 2 logs after 7 days incubation, and 5 logs after 14 days. The virus is unstable at $56^{\circ} \mathrm{C}$ or $60^{\circ} \mathrm{C}$. The data indicate that the infective titer decreased by 3 and 6 logs, respectively, after 30 and $60 \mathrm{~min}$ heating at $56^{\circ} \mathrm{C}$. It is generally accepted that EIA virus is inactivated by heating at $60^{\circ} \mathrm{C}$ for $60 \mathrm{~min}$ [27].

\section{Biological Properties}

The virus seems to propagate much slower in cultured cells than other animal viruses. It takes 21 to $24 \mathrm{~h}$ to produce the progeny virus [41]. The exact reason for this is unknown, but EIA virus has an enzyme of RNA-dependent DNA polymerase and has a DNA-dependent stage in its replication as already mentioned. Accordingly, there should be a pathway of genetical information from RNA to DNA and DNA to RNA during virus replication. It may therefore take longer time for the virus to propagate.

It has been reported that there are many strains of EIA virus which are immunologically so distinct that they are differentiated from one another by the neutralization test [37]. Accordingly, each strain has a type-specific antigen originating on the surface of the virus. On the other hand, it has group-specific antigens which are demonstrated in complement fixation (CF) and immunodiffusion tests. The group-specific antigen reacts commonly with the antiserum obtained from horses experimentally infected with antigenically distinct virus strains. To what extent these antigenically distinct virus strains differ from one another is a problem of interest to be solved in future.

A type specific antigen, gp76 was also demonstrated in the virion (probably on the surface of the virion) and its antigenicity was shown against a serum sample obtained from the horse infected with the homologous virus strain [79].

Hemagglutination (HA) by EIA virus was demonstrated using guinea pig erythrocytes [97]. The HA activity was destroyed by virus-disrupting lipid solvents.
The virus propagates in the infected horse and induces a fit of recurrent fever. Viremia occurs in every febrile stage. It has been clarified that variants of EIA virus which are antigenically different from one another appear in each febrile stage, and this is believed to be one of the major reasons for the recurrent fever observed in chronically infected horses and the life-long persistent infection [38]. This phenomenon was not noticed when the virus was propagated in cultured cells. The multiformity of the virus itself, the target cells in host animals, the mode of replication of the virus and the interaction between the virus and antibody in infected animals are considered to be related to the occurrence of this phenomenon. Little is known, however, on this and it is the most important problem to be solved.

The host range of EIA virus is extremely limited. The results so far obtained indicate that the virus can propagate in cultured cells from only horses such as leukocytes, bone marrow, kidney, spleen and dermal cells. All attempts to infect cells derived from animals other than equidae with EIA virus have been unsuccessful except for canine thymus cell lines, as mentioned in a previous chapter [4].

Vertical infection from the mare to the foal in nature was statistically examined by Hanagata and Akiyama. As a result, 148 out of 833 infected horses were found to be blood related. They suggested that the foals from infected mares would also be very likely to be infected [14]. Moreover, it is demonstrated that 8 out of 20 foals from mares which were positive for agar-gel immunodiffusion (AGID) were also positive for the test at 6 to 12 months after parturition (unpublished data). Kemen and Coggins published similar results, saying that 12 out of 52 foals from infected mares were positive for AGID [21]. The route of infection was not known. On the other hand, Sugiura (unpublished data) has statistically investigated the transmission from stallions to foals to determine the possibility of genetic transmission in 200 infected horses. There was no tendency to a positive/negative ratio among foals out of 148 stallions.

The incubation period varies according to the dosage administered and the strains. The incubation period was often prolonged to as long as 67 days when an extremely small quantity of the virus had been used in the inoculation [26]. Tanaka 
investigated the incubation periods of 179 horses inoculated with various kinds of viral materials [107]. Sugiura found (unpublished data) that healthy horses had'been inoculated with $100 \mathrm{ml}$ of samples of blood from a naturally infected horse for 10 years after the disease was diagnosed. Of them, 7 horses showed clinical symptom within three weeks after inoculation, but 2 did not show any sign of illness within several weeks, but produced a precipitating antibody. The remaining one horse, inoculated in the 7th experimental year, showed no clinical signs and had no precipitating antibody till 3 months after inoculation. 1.1 $\mathrm{mg}$ of corticosteroid was then injected into this horse for 5 days. The horse produced a precipitating antibody 3 weeks later. These results suggest that the difference in the incubation period will depend on the inoculation dosage. The relationship between the inoculation dosage and degree of illness is of interest in the case of infectious diseases including HIV infection.

\section{Classification}

Of the viral properties investigated so far, the following are characteristic of EIA virus: (1) The virus has high-molecular-weight RNA that is estimated to be approximately $5.5 \times 10^{6}$ daltons, and it is dissociated by heat treatment to 2 molecules of $34 \mathrm{~S}$ subunit. (2) The virus contains reverse transcriptase and it shows DNA dependent replication. Virion RNA is reverse-transcribed into DNA and integrated into the chromosomal DNA of the host cell to form a provirus. (3) The base composition and its structure are very similar to those of Retroviridae viruses. (4) The polypeptide composition of the virus appears to be similar to that of the RNA tumor virus. The major structural protein is p25 that has a group-specific antigenicity. (5) Morphologically, the virus consists of an envelope, surface projections, an inner particle shell and a core (nucleoid). Its fine structure is hardly recognizable even by electronmicroscopy. (6) The buoyant density is 1.15 to 1.16 in $\mathrm{CsCl}$ and sedimentation coefficient is approximately $650 \mathrm{~S}$. (7) The virus is resistant to ultraviolet irradiation and trypsin digestion. (8) The virus is easily inactivated by lipid solvents, detergents, acid, alkali and heat treatment. (9) Host range of the virus is limited and the virus requires rather long time for propagation. (10) There occurs antigenic variants of EIA virus in the horse suffering from
EIA.

These properties are quite similar to those of RNA tumor virus. Retroviridae is currently classified into 7 genera [8]. Taking such characteristic properties of EIA virus as no oncogenicity, base composition, structure of virus proteins, reverse transcriptase property, fine structure of the virion, viral replication mode, yielding of variants in infected animals, and others, into consideration, EIA virus is included in genus Lentivirus of family Retroviridae, with human, simian, feline and bovine immunodeficiency viruses, Visna/Maedi virus, and caprine arthritis/encephalitis virus.

\section{Immunology}

1. Hypergammaglobulinemia

Hypergammaglobulinemia is one of the most remarkable features of the disease, and immunological research on the disease is mainly conducted on the immunoglobulin composition of hypergammaglobulinemia. The main substance of the hypergammaglobulinemia is $\operatorname{IgG}$, although antibody activity to the major structure protein of the virus, $\mathrm{p} 25$, is maintained by $\operatorname{IgG}(\mathrm{T})$ in the chronic stage. IgG producing cells have not been identified, although Yamamoto suggested that small $r$ cells grew in the chronic stage [116, 117].

Hypergammaglobulinemia has also been observed in human myeloma and some of infectious diseases such as the Aleutian disease of mink and in AIDS [11, 93, 96].

McGuire et al. reported that $90 \%$ of infected horses showed an increase in IgG, and some immunoglobulin subclass levels were two- and three-fold greater than normal. $\operatorname{IgG}(\mathrm{T})$ was high in $36 \%$ of infected horses [51]. It increased early in the infection and decreased later when the $\operatorname{IgG}$ level remained high. IgM was high in $63 \%$ of the cases and aggregating immunoglobulin in $14 \%$. They suggested that the hypergammaglobulinemia of infected horses was heterogeneous with respect to immunoglobulin class and was consistent with chronic antigenic stimulation, most likely by viral antigens.

It will be interesting to know whether or not the increased immunoglobulin still maintains its the antibody activity, and to determine its immunological and biological activity. If they have antibody activity to any viral component, it will be an 
EIA-virus-related glycoprotein on the surface of infected cells, although we do not have any evidence that infected cells are exhibiting viral antigens on their surface in the chronic stage. It will be also interesting to see what kind of cells produce these increased immunoglobulins.

\section{Cellular Immunity}

Cellular immunity in EIA has not been as well characterized as humoral immunity, but there it is thought that cellular immunity is more effective than humoral immunity in resisting against EIA [7]. Banks has shown that the monocytes of infected horses failed to migrate from capillary tubes and their adherence to erythrocytes was activated. This increased adherence will be a reaction to the viral protein on the erythrocyte [97-99]. Kono et al. showed that lymphocyte response to the virus antigen increased shortly after the primary infection and became strong after the recurrence of signs [39]. In chronic infections, however, horses occasionally showed a spontaneous increase in lymphocyte response to the antigen. Fujimiya et al. reported the presence of direct cytotoxicity but the absence of antibodydependent cellular cytotoxicity in EIA [12]. The existence of antibody-dependent cell-mediated cytotoxicity acting on autologous EIA-virusinfected lymphoblasts was demonstrated in vitro at the beginning of an acute attack of the disease. Cytotoxic activity was not found or was very low during chronic infection. Reactivity of peripheral blood lymphocytes to Protein A and allogeneic cells in vitro was significantly suppressed in the presence of an acute serum, while the reactivity to PHA was at the normal level [13]. They concluded that immunopathogenesis in EIA virus and HIV infection are similar in the way in which they affect the immune response of the host, on the basis of data on the quantitative analysis of lymphocyte activity in infected horses [13].

\section{Immunosuppression}

Immunosuppression is a typical feature of most retrovirus infections of both man and animals, although there has been only a little evidences of this in EIA till recently. McGuire et al. suggested that production of IgG in response to exogenus antigenic stimulation was suppressed by increased $\operatorname{IgG}(\mathrm{T})$ in EIA [45, 46]. Fujimiya et al. reported that the activated antibody-dependent cytotoxicity reaction in horses by IgG subclass antibody is efficiently inhibited by $\operatorname{IgG}(\mathrm{T})$ subclass antibody. Newman et al. reported the transient suppression of the immune system as a loss or decrease in antigen-specific and polyclonal lymphocyte proliferation following infection. They suggested that EIA virus is similar to other retroviruses in its ability to suppress the immune system [78].

\section{Auto-immunity}

EIA is one of the auto-immune diseases which include the Aleutian disease of mink, and infection with lactic dehydrogenase virus of mice and others, because immunoglobulin deposition in glomerulonephritis [1,2] and immunocomplex disease $[6,92]$ are commonly observed in these diseases.

Cold and warm hemagglutinins appeared in the circulating blood of infected horses [86-91]. The different temperature for agglutinating erythrocytes is probably due to the different temperature suitable for binding the antibody to the antigen.

\section{Pathogenesis}

\section{Recurrence and Persistence}

There are always antigenic variants of EIA virus that have not been neutralized by an antibody in chronically infected horses. It is concluded that persistent viremia caused by EIA virus is established on a continuous cycle formed by the appearance and propagation of antigenic variant virus in the body. The neutralizing antibody to this variant is produced in the host and it stimulates the further appearance of another new antigenic variant. In conclusion, recurrent fever is induced as a result of marked propagation of an antigenic variant [29, 38]. In infected horses, however, fever recurs frequently within 6 months after infection, and rarely after that. These facts suggest that an infected horse may acquire immunity, which inhibits the propagation of antigenic variants in the body, when a certain period of time has passed after infection. A working hypothesis was established which said that cellular immunity might participate in the mechanism inhibiting the recurrence of fever by administering with immunosuppressive drugs [29].

Kono et al. investigated the variation in the virus in vivo [38]. They compared the virus strains from 
a horse with serial pyrexia. The antigenicity of the viruses isolated in each febrile stage differed. A neutralizing antibody to the strain which appeared in the pyrexia stage was produced one to two weeks after the febrile stage. The antibody did not neutralize the variants which appeared foregoing pyrexia. This variation may be explained by the antibody pressure theory although this theory cannot explain the prolonging of the interval of pyrexia [50].

\section{Anemia}

The cause of anemia seems to be hemolysis and impaired bone marrow. In the acute stage, red blood cells (RBC) binding with virus particles or hemagglutinin of the virus are phagocyted by macrophages and polynuclear-cells. The phagocyted RBC are demonstrated as sideroleukocytes [15-19]. Decreased production of RBC in bone marrow [80-82, 84], decreased complement level in plasma and half life span of RBC $[48,83,85$, $94]$, and the presence of cold hemagglutinin [90, 91] support the idea set out above.

\section{Diagnosis}

\section{Serological Diagnosis}

Diagnosis of the disease by serological tests was one of the most important purposes. Humoral

Table 1. Humoral antibody detected in the horses infected with equine infectious anemia virus

\begin{tabular}{|c|c|c|c|c|c|}
\hline Antibody & $\begin{array}{l}\text { Serological } \\
\text { Test }\end{array}$ & Specificity & $\begin{array}{l}\text { First } \\
\text { Appearance }\end{array}$ & Titer & Duration \\
\hline $\begin{array}{l}\text { Precipitating } \\
\text { Antibody }\end{array}$ & $\begin{array}{l}\text { Agar Gel } \\
\text { Immunodiffu- } \\
\text { sion Test }\end{array}$ & $\begin{array}{l}\text { Group } \\
\text { Specific } \\
\text { for EIAV }\end{array}$ & $\begin{array}{l}14 \text { to } 50 \text { Days } \\
\text { after } \\
\text { Inoculation } \\
2 \text { to } 10 \text { Days } \\
\text { after the } \\
\text { First Pyrexia }\end{array}$ & $\begin{array}{l}1: 4 \text { to } 1: 16 \\
(\operatorname{Max} 1: 128)\end{array}$ & for Life \\
\hline $\begin{array}{l}\text { Complement- } \\
\text { Fixing } \\
\text { Antibody }\end{array}$ & $\begin{array}{l}\text { Complement } \\
\text { Fixation Test }\end{array}$ & $\begin{array}{l}\text { Group } \\
\text { Specific } \\
\text { for EIAV }\end{array}$ & $\begin{array}{l}14 \text { to } 50 \text { days } \\
\text { after } \\
\text { Inoculation } \\
2 \text { to } 10 \text { Days } \\
\text { after the } \\
\text { First Pyrexia }\end{array}$ & Around 1:128 & $\begin{array}{l}\text { for Life (Not } \\
\text { detected after } \\
3 \text { to } 60 \text { Days) }\end{array}$ \\
\hline $\begin{array}{l}\text { Complement- } \\
\text { Fixation } \\
\text { Inhibiting } \\
\text { Antibody }\end{array}$ & $\begin{array}{l}\text { Complement } \\
\text { Fixation } \\
\text { Inhibition } \\
\text { Test }\end{array}$ & $\begin{array}{l}\text { Group } \\
\text { Specific } \\
\text { for EIAV }\end{array}$ & & $\begin{array}{l}\text { Maximum } \\
1: 512\end{array}$ & for Life \\
\hline $\begin{array}{l}\text { Neutralizing } \\
\text { Antibody }\end{array}$ & $\begin{array}{l}\text { Neutralization } \\
\text { Test }\end{array}$ & $\begin{array}{l}\text { Type } \\
\text { Specific } \\
\text { for strain }\end{array}$ & $\begin{array}{l}10 \text { to } 60 \text { Days } \\
\text { after } \\
\text { Inoculation }\end{array}$ & $\begin{array}{l}1: 128-1: 256 \\
(\text { Max. 1:2,048) }\end{array}$ & for Life \\
\hline $\begin{array}{l}\text { Fluorescent } \\
\text { Antibody }\end{array}$ & $\begin{array}{l}\text { Indirect } \\
\text { Fluorescent } \\
\text { Test }\end{array}$ & $\begin{array}{l}\text { Group } \\
\text { Specific } \\
\text { for EIAV }\end{array}$ & & & for Life \\
\hline $\begin{array}{l}\text { Hemagglutina- } \\
\text { tion } \\
\text { Inhibiting } \\
\text { Antibody }\end{array}$ & $\begin{array}{l}\text { Hemagglutina- } \\
\text { tion } \\
\text { Inhibition } \\
\text { Test }\end{array}$ & $\begin{array}{l}\text { Type } \\
\text { Specific } \\
\text { for strain }\end{array}$ & & Max. 1: 256 & for Life \\
\hline $\begin{array}{l}\text { Indirect } \\
\text { Hemagglutina- } \\
\text { ting Antibody }\end{array}$ & $\begin{array}{l}\text { Indirect } \\
\text { Hemagglutina- } \\
\text { tion Test }\end{array}$ & $\begin{array}{l}\text { Group } \\
\text { Specific } \\
\text { for EIAV }\end{array}$ & $\begin{array}{l}14 \text { to } 50 \text { Days } \\
\text { after } \\
\text { Inoculation } \\
2 \text { to } 10 \text { Days } \\
\text { after the } \\
\text { First Pyrexia }\end{array}$ & $\begin{array}{l}\text { Max. } \\
1: 10,240\end{array}$ & for Life \\
\hline
\end{tabular}


antibodies detected in infected horses with EIA virus are shown in Table 1 [101].

Successful antibody detection was carried out first by Kono and Kobayashi (1966) using culture fluid from infected horse leukocyte culture as antigen by $\mathrm{CF}$ test $[34,35]$. In general, $\mathrm{CF}$ antibody appears 17 to 40 days after inoculation or 5 to 20 days after onset of fever. This period is prolonged in a horse with a long incubation period. The result of CF test turned negative 2 to 60 days after the antibody became positive, although the antibody was present. Because specific $\operatorname{IgG}(\mathrm{T})$ antibodies to EIA virus block complement fixation by $\operatorname{IgG}$ when $\operatorname{IgG}(\mathrm{T})$ predominates $[49,77,110]$. Therefore, it is necessary to test both $\mathrm{CF}$ and complement fixation inhibition tests for diagnosis of EIA.

Neutralizing antibody can be demonstrated by means of horse leukocyte culture by inhibition of CPE as indicator [27, 109], as well as in horses [108]. Neutralizing antibody was demonstrated in infected horses 23 to 26 days after onset of pyrexia. The antibody remains for life and maintains the highest level for a long time. The titer was not influenced by any of recurrent febrile attacks.

AGID is the most common strategy for diagnosis of EIA in the world. In Japan, this test was officially introduced by law in 1978 for diagnosis of EIA. Details are described in the next chapter.

Horses infected with various immunologically distinct strains of EIA virus have precipitating antibody against the purified viral antigen prepared from horse leukocyte cultures infected with a strain of the virus [62, 73] or against crude antigen prepared from infected horse spleen [9]. Antibodies demonstrated with both antigens are identical [64].

Antibody has been detected over a period from 2 to 10 days after the peak of the first pyrexia [74] and seems to remain positive for life. The highest antibody titer was 1: 128 in naturally or experimentally infected horses [60]. Its level is, however, considerably variable in the course of disease. The titer seems to decrease remarkably in horses that have had no pyrexia for a few months [67].

Intracellular EIA viral antigen can be detected in cultured leukocytes by the direct $[10,47]$ or indirect [112, 113] fluorescent antibody method. There is still the risk that testing materials are contaminated with organisms, such as EHV-2, because a germ free or SPF horse was not used to prepare the antibody and culture cells.

Hemagglutination inhibiting antibody was demonstrated by Sentsui et al. using horse and hamster RBC coated with whole virus or hemagglutinin from virus [97-99]. The antibody is type specific and the reactivity is the same as that of neutralizing antibody.

The antibody to EIA virus was detected by indirect hemagglution test [104] using the purified antigen by affinity chromatography [103]. The reactivity is the same as that of the agar gel immunodiffusion antibody while antibody titer was expressed at a higher level.

The antibody to EIA virus is also detected by enzyme-linked immunosorbent assay (ELISA) for diagnosis of the disease $[100,102,105,115]$. The test was established in 1994 by the Japan Racing Association and can be used for screening infected horses although the test is not officially admitted in Japan. It needs two days to check for EIA at quarantine by AGID test. In contrast, ELISA test is completed within three hours under the new quarantine system. However, horses are also checked antibody to EIA virus by AGID test in parallel with ELISA test. In the test, antigen is purified by sucrose gradient ultracentrifugation and adhered to 96-well microtiter plates (Nisseiken, Co., Tokyo). Serum samples diluted 808fold with diluent are reacted in the plate for 40 $\min$ at $37^{\circ} \mathrm{C}$. The plate is washed and then reacted with horseradish peroxidase-labeled anti-horse $\operatorname{IgG}(\mathrm{H}+\mathrm{L})$ for $30 \mathrm{~min}$. The plate is washed again, and after adding the reagent for color development, it is left for $10 \mathrm{~min}$. Optical density is measured after stopping the reaction. A sample that shows higher density than the reference serum is judged as positive. All the steps from dilution of the serum samples to judgment of the results are automatically conducted by an automated laboratory workstation (Biomek 1000 and Sideloader, Beckman, U.S.A.).

\section{Immunodiffusion Test}

Although many attempts had been made to develop a reliable diagnostic test, EIA was still difficult to diagnose. For example, CF and neutralization tests have been shown to be specific for EIA and detect EIA. However, CF antibody is usually detectable for only a short period of time after the first fever, although it reacts with anti- 
genically different strains of EIA virus which are distinguishable from one another by neutralization test. Neutralizing antibody, on the other hand, persists for a long period of time, but does not react with antigenically different virus strains. Accordingly, both tests are not entirely satisfactory for diagnostic use. From 1970 to 1971, however, Coggins and Norcross, and Nakajima and Ushimi developed immunodiffusion test for EIA [9, 73]. The immunodiffusion test detects EIA-virusspecific precipitating antibody, which appears early in the infection, remains in the serum for a long period of time probably for life of the animal, and can be demonstrated in all infected horses. Moreover, in the experiment to learn correlation between the presence of precipitating antibody and infectiousness of EIA, blood from almost all serologically positive horses produced EIA infection in experimental horses. These findings prove immunodiffusion to be specific and the most practical test at present for the diagnosis of EIA [54, 58, 67].

1) Procedures for Immunodiffusion Test

(1) General Procedures

$0.8 \%$ of purified agar (Special Agar-Noble; Difco) is prepared in $0.85 \% \mathrm{NaCl}$ solution containing $0.1 \%$ sodium azide $\left(\mathrm{NaN}_{3}\right)$. Sodium azide inhibits growth of bacterial and fungi. The agar is dissolved by boiling for $10 \mathrm{~min}$. Then, $4.5 \mathrm{ml}$ of the agar solution is poured on microscope slides $(26 \times 76 \mathrm{~mm})$. The plate is allowed to harden.

A seven-well puncher with one central and 6 peripheral wells is used for cutting wells in the agar plate. Wells are $5 \mathrm{~mm}$ in diameter and peripheral wells are placed at a distance of $3 \mathrm{~mm}$ from the central well. The puncher for this purpose can be purchased. Three sets of these combined wells can be prepared on one agar plate.

Antigen is filled in the central well and reference positive serum in the left and right peripheral wells as shown in Fig. 3. Test sera are sampled in the other four peripheral wells. Accordingly, 12 serum samples can be tested using one agar plate. Approximately $0.05 \mathrm{ml}$ of sera or antigen is needed for each well.

After sampling, the plate is incubated in a moist chamber for 4 days. Although the reference precipitation lines can be observed within $24 \mathrm{~h}$, weak reactions are not visible at this time. When the reaction is completed, the plate is photographed unstained to obtain a record. If it is

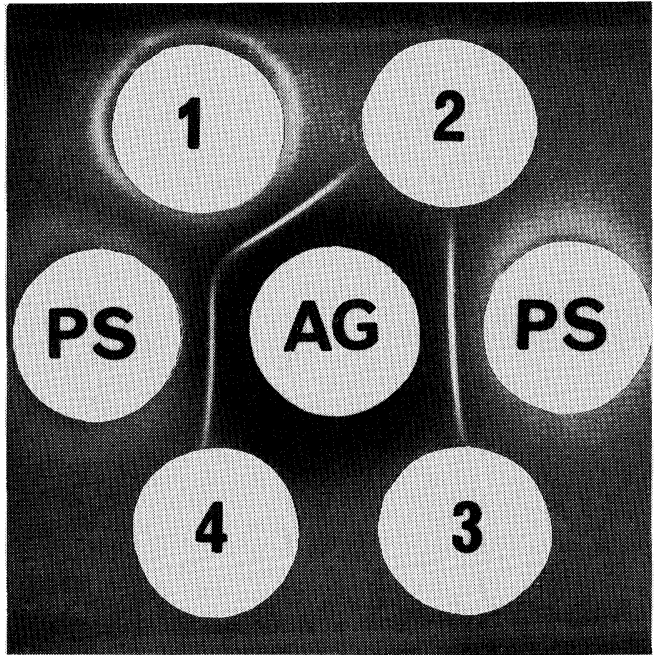

Fig. 3. Immunodiffusion test for the diagnosis of equine infectious anemia. Antigen (AG) is placed in the central well and reference positive serum (PS) in the left and right peripheral wells. A reference positive precipitation line must be formed always between antigen and each antiserum after 24 h. Serum samples to be tested are placed in wells $1,2,3$ and 4 . When a precipitation line joining with the control appears (Sample 1), the sample concerned is judged to be a positive one. The other samples (Sample 2, 3 and 4) show a typical negative pattern in immunodiffusion test.

difficult to get photographs, accurate drawing is necessary. When it is necessary to preserve the plate, it is washed for 3 days in saline to remove the substance that is not involved in the reaction, and then, rinsed for a few hours in distilled water to remove $\mathrm{NaCl}$. Finally, the plate is dried, stained with amido black, destained and preserved. Staining solution is prepared by mixing $0.1 \mathrm{~g}$ of amido black $10 \mathrm{~B}, 70 \mathrm{ml}$ of methyl alcohol, $10 \mathrm{ml}$ of acetic acid and $20 \mathrm{ml}$ of distilled water.

In order to obtain accurate and constant results at testing by immunodiffusion, it is recommended to use disposable plastic plates in which agar gel and wells are already prepared. They are commercially available.

(2) Preparation of Immunodiffusion Antigen

Purified EIA virus was used as antigen first. For field application of the test, however, it was necessary to develop simple procedures for preparation of large amounts of EIA-specific antigen [74]. At present, the antigen is prepared by collecting infected cultures including cells in a 


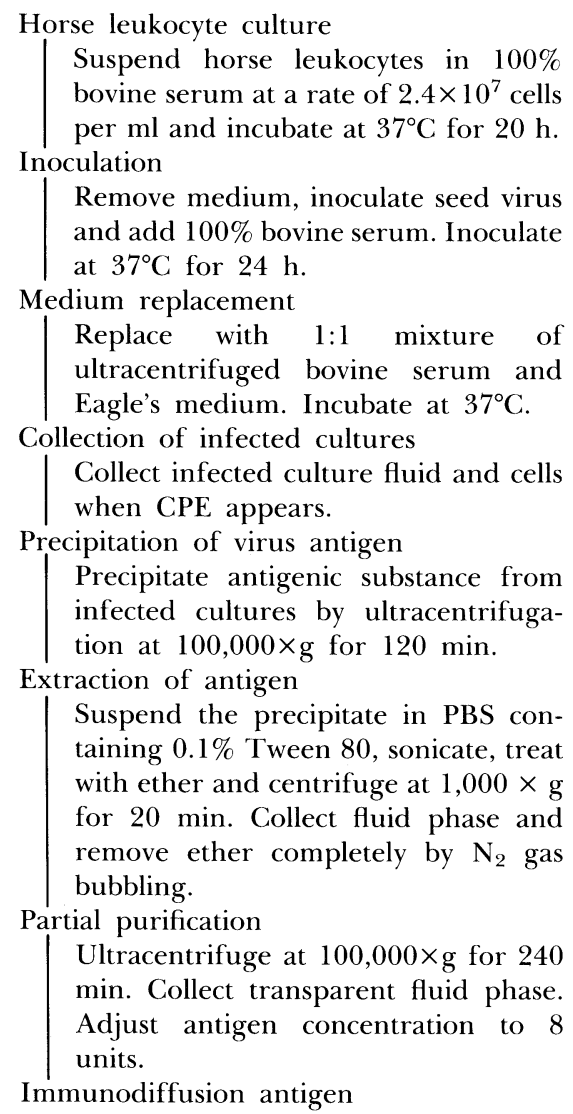

Fig. 4. Procedures for immunodiffusion antigen preparation by horse leukocyte culture technique

small amount of phosphate-buffered saline containing $0.1 \%$ Tween 80 and by treating them with two volumes of ether twice. These procedures are shown in Fig. 4.

There is an optimal antigen-antibody ratio in immunodiffusion reaction. If the activity of antigen or antibody is greatly unbalanced, a precipitation line does not appear or is only weak. An optimal antigen concentration was therefore determined as described later. Based on the experimental data, the antigen is adjusted to 8 units before use.

(3) Preparation of Reference Positive Serum

Reference positive serum is obtained from a horse experimentally infected with EIA virus. As antiserum with a titer of 4 units was shown to react most widely against antigens at various concentrations, the serum is inactivated at $60^{\circ} \mathrm{C}$ for $60 \mathrm{~min}$, and its titer is adjusted to become 4 units before use. Then, it is confirmed to match with highly purified virus antigen and to form only one distinct precipitation line.

(4) Reading and Judgment of Immunodiffusion Test

Usually, antigen is filled in the central well and reference positive serum in the left and right peripheral wells. Accordingly, reference precipitation lines always appear between the antigen and each reference positive serum, slightly toward the wells of the positive serum (Fig. 3). The control lines are the basis for reading the test. If no distinct control line is formed, the test must be repeated.

The type of reaction varies with the strength of the serum being tested. In our laboratory, only when the control line joins with and forms a continuous complete line with the line between the test serum and antigen (sample 1 in Fig. 3), the sample is judged to be a positive one. When the control line bends slightly toward the inside of the well of the test serum but does not form a complete line, or the control line bends and hits the inside of the well of the test serum, this sample is regarded as suspectedly positive $( \pm)$, although the sample may contain precipitating antibody at a low level. One of the reasons why these samples are regarded as suspected is that there have been only limited experimental data indicating whether these cases retain active EIA virus or not. This strongly suggests the need to do more experiments on this. Tests are usually repeated in these cases and we wait until the sample turns out to be positive.

When the control line continues into the test serum well without bending or bends toward the outside of the well as shown in the case of samples 2, 3 and 4 of Fig. 3, the test serum is regarded as a negative one.

Rarely, a precipitation line formed does not join the control line smoothly, or cross the control line. This is due to the reaction other than EIA. Accordingly, these reactions are regarded as nonspecific ones.

2) Characteristics of Immunodittusion Antigen (1) Antigen suitable for Immunodiffusion Test Immunodiffusion antigen suitable for the diagnosis of EIA seems necessary to be qualified by the following points. 1) The antigen is identical in its reactivity with an antigen prepared from highly purified EIA virus. 2) The antigen reacts identically against serum samples from horses infected with 
any strains of EIA virus. 3) The antigen forms only one distinct precipitation line against reference positive serum. 4) The antigen reacts to any serum samples that contain precipitating antibodies ranging from high to low levels of titer. 5) The antigen does not show any specific reaction against serum samples from noninfected horses.

One of the most important factors is antigen concentration. The fundamental idea is that the antigen should react with any positive samples obtained from the field ranging from high to low levels of antibody titer. Box titration was therefore carried out in agar gel to determine the patterns of reaction between antigen and antibody with various titers. The antigen and positive serum used in the experiment had a titer of $1: 32$ and 1:128, respectively, the latter of which was the highest value determined by serial twofold dilution among positive cases so far experienced in Japan. The results indicate that the 8 unit antigen can react and form a precipitation line against any positive serum samples found in the field. Therefore, the 8 unit antigen is recommended for use in the diagnosis of EIA.

(2) Antigenic Relationship among Antigens Prepared from Different Sources

At present immunodiffusion antigen can be produced from infected horse spleen, infected horse leukocyte cultures, persistently infected equine dermal cell cultures, infected horse kidney cell cultures, and others. Antigens from infected horse leukocyte cultures and infected horse spleen have already been proved to be antigenically identical [64]. Antigens from the last 3 infected cell cultures were prepared and their antigenic relationship were determined [56]. As a result, their antigenic activities were found to be identical with one anotehr, and consequently, any of the antigens described above can be used in immunodiffusion test.

(3) Physicochemical Properties of Antigen

Purified EIA virus has antigenic activity in immunodiffusion reaction, but intact virions have no antigenicity. When the virus is disrupted with ether, antigenic activity is demonstrated [74]. In addition, the antigen can react with any serum samples from horses experimentally infected wth antigenically distinct virus strains. These findings indicate that the antigen involved in the immunodiffusion test is a group-specific component of EIA virus that is derived from inner structures of the virus rather than surface ones.

The antigen is a small protein with a molecular weight of 25,000 daltons, sedimentation coefficient of $2.1 \mathrm{~S}$, density of $1.2 \mathrm{~g} / \mathrm{cm}^{3}$, and isoelectric point of 5.8. The antigen is stable for $4 \mathrm{~h}$ but inactivated after $24 \mathrm{~h}$ at $\mathrm{pH} 2.0$. The activity is lost following the action of trypsin for $2 \mathrm{~h}$. The antigen is quite stable at $-20^{\circ} \mathrm{C}$ or lower temperatures, but it is inactivated at $56^{\circ} \mathrm{C}$ for $30 \mathrm{~min}$. The antigenic activity is reduced to one half every 3 days at $37^{\circ} \mathrm{C}$. 3) Characterization of Precipitating Antibody (1) Appearance and Development of Precipitating Antibody

Precipitating antibody has been detected in all 71 horses experimentally infected with various strains of EIA virus. Antibody appears in the serum sometime from 4 to 12 days after the first pyrexia and it remains positive for life, but in the case of very weakly infected horses, the antibody is demonstrated 30 to 60 days after infection without any symptoms of EIA.

The antibody titer is generally increased by recurrent fever, but its level is, varies considerably during the course of disease. And it seems to decrease remarkably especially after the horse has spent a few months without pyrexia.

Serum samples obtained from horses infected with equine influenza virus, EHV-1 and -2, equine arthritis virus and Japanese encephalitis virus contain, of course, no precipitating antibody specific for EIA.

(2) Titer of Precipitating Antibody

Antibody titer in 171 serum samples collected from the field was examined. The maximum antibody titer among them was 1:128. More than $60 \%$ of titers were between $1: 4$ and 1:16 [62].

The maximal titer in approximately 200 serum samples taken periodically from 9 horses experimentally infected with EIA virus was also $1: 128$. A titer of $1: 128$ therefore seems to be the upper limit in Japan under the procedure performed in our laboratory.

(3) Relationship to Antibodies Demonstrated by Other Serological Techniques

Development of precipitating, CF, neutralizing and indirect hemagglutinating antibodies in an experimentally infected horse is measured. Of them, development of indirect hemagglutinating antibody is similar to that of precipitating antibody. However, the others including hemagglutination inhibiting antibody are different from 
precipitating antibody in their development pattern.

(4) Physicochemical Properties

Precipitating antibody is detectable in $7 \mathrm{~S}$ fraction but not in $19 \mathrm{~S}$ fraction of serum samples obtained in both early and late stages of infection $[62,111]$. The antibody is shown to be present in IgG, IgG (T) and IgA like immunoglobulin fractions. The antibody loses its activity $4 \mathrm{~h}$ after dialysis against buffers at $\mathrm{pH}$ 2.0. It is, however, stable when heated and not inactivated even at $65^{\circ} \mathrm{C}$. The antibody keeps its activity without any change for $3 \mathrm{~h}$ during treatment at $56^{\circ} \mathrm{C}$ or for 7 days at $37^{\circ} \mathrm{C}$.

\section{Prevention}

\section{Control in Japan}

The Japanese Government has designated EIA as a malignant infectious disease under the Domestic Animal Infectious Diseases Control Law, and a "Test and Slaughter" system has been applied to its control under the law. Previously, a horse was diagnosed as EIA by a typical recurrent fever and clinical symptoms. In addition, in the case of an asymptomatic type, sideroleukocyte detection in the blood of the jugular vein was carried out for the diagnosis of EIA in Japan. As a result, the number of infected horses decreased from year to year to a level of hundreds, although more than 10,000 EIA-positive horses were detected in 1950.

Table 2. Number of horses positive for equine infectious anemia in recent years in Japan

\begin{tabular}{lr}
\hline Year & No. of positive horses \\
\hline 1970 & 194 \\
1971 & 175 \\
1972 & 127 \\
1973 & 270 \\
1974 & 89 \\
1975 & 232 \\
1976 & 54 \\
1977 & 29 \\
1978 & 104 \\
1979 & 198 \\
1980 & 44 \\
1981 & 15 \\
1982 & 5 \\
1983 & 4 \\
$1984-1992$ & 0 \\
\hline
\end{tabular}

However, development of a specific and an effective diagnostic procedure was delayed as mentioned above, and complete control of EIA was not be possible.

In 1978, a diagnostic method by immunodiffusion was introduced under the law. After that, the number of positive horses decreased rapidly as shown in Table 2 . The disease has been completely controlled in Japan since 1984.

EIA has remained prevalent in some areas of the world and, since the movement of horses has been actively carried out internationally, careful attention must continually be paid continuously to the control of EIA.

\section{Protection}

Immunization with killed virus has been attempte by many researchers, but it is difficult to evaluate whether the immunity was acquired or not in the case of EIA. In contrast to this, recovered carriers are known to become resistant to reinfection. In view of this, the use of attenuated or avirulent virus for giving immunity against EIA seems to be logical.

It was observed that some horses manifested a rise in $\mathrm{CF}$ and neutralizing antibodies, but not symptoms, when inoculated with virus that had been subjected to 31 or more passages in horse leukocyte culture [31]. These horses resisted to reinoculation with virulent EIA virus that was homologous with the original virus in a neutralization test, 130 days after the original inoculation.

Furthermore, a clonal virus that had passed 50 times in the horse leukocyte cultures had no pathogenicity against horses and showed no apparent protection in vivo even when larger inoculation doses, such as $10^{6.8}$ and $10^{8.2}$ TCID $_{50}$ had been inoculated [36]. Repeated inoculations, however, caused a gradual increase in neutralizing antibody titer. These horses were challenged with virulent virus that was immunologically homologous to avirulent virus, 200 days after the first inoculation. All of them resisted infection, presenting neither clinical signs, viremia, nor any rise in $\mathrm{CF}$ or neutralizing antibody titer.

In all cases through these experiments, immunological agreement between the immunizing virus and challenge virus was indispensable for the establishment of an immune state [36].

These results indicate that complete protection against EIA by vaccination is extremely difficult. 
Accordingly in the present situation, the test and isolation or slaughter system is the best way to control EIA for the time being.

\section{Conclusion}

Since the culture of EIA virus in vitro, which was considered the most difficult work in the history of EIA research, was successfully established by Kobayashi in 1961, many useful reports on EIA have appeared in Japan in the two decades, and Japanese workers have led world research on. It is therefore not too much to say that current research progress on EIA is due to the establishment of the horse leukocyte culture technique that has made possible EIA virus propagation in vitro and determination of the virus infectivity. There is still no other method that can replace the leukocyte culture. This achievement must be evaluated especially from viewpoints of its originality and far-reaching effect. This is really a great work.

When the history of studies on EIA is reviewed, it can be divided roughly into the following 3 parts. (1) prior to the confirmation of EIA as an infectious disease, (2) after the demonstration of the etiological agent of EIA as a filterable virus by Vallée and Carré, and (3) after Kobayashi made it possible to propagate the etiological virus of EIA in vitro and to perform quantitative assay of the virus.

Through these steps, the pathogenesis of EIA has been gradually clarified. It took more than 150 years for EIA research to reach its present level after Lignée reported the occurrence of a hematological disease prevailing among horses in 1843 in France as the first description of EIA. It is a very long history. Even at present, however, the mechanisms of appearance of variants, persistent infection for life and anemia, the relationship among virus propagation, host responses and pathological changes and the development of vaccine against EIA, etc. still remain to be dealt with, although it has become to diagnose the disease by serologic tests.

There are still many infected horses in the world, especially in some regions of Southeast Asia, South America, etc. It will be difficult to adopt the "Test and Slaughter" system in these areas, mainly for economic reason. Studies on how to control the disease including vaccine develop- ment, seem to be needed in these cases.

On the other hand, it is disappointing that research on EIA has slackened off throughout the world, although the similarity of EIA virus to causative virus of AIDS has been pointed out, and furthermore, there are still many points to be clarified as mentioned above. It is to be hoped that research activity will be restored to its former level.

\section{References}

1. Banks, K.L. and Henson, J.B. 1972. Immunological mediated glomerulitis of horses. II. Antiglomerular basement membrane antibody and other mechanisms in spontaneous disease. Lab. Invest. 26: 708-715.

2. Banks, K.L., Henson, J.B., and McGuire, T.C. 1972. Immunological mediated glomerulitis of horses. I. Pathogenesis in persistent infection by equine infectious anemia virus. Lab. Invest. 26: 701-707.

3. Benton, C.V., Brown, B.L., Harshman, J.S., and Gilden, R.V. 1981. In vitro host range of equine infectious anemia virus. Intervirol. 16: 225-232.

4. Bouillant, A.M.P., Kielsen, K., Ruckerbauer, G.M., Samagh, B.S., and Hare, W.C.D. 1986. The persistent infection of a canine thymus cell line by equine infectious anaemia virus and preliminary data on the production of viral antigens. J. Virol. Meth. 13: 309-321.

5. Charman, H.P., Bladen, S., Gilden, R.V., and Coggins, L. 1976. Equine infectious anemia virus: Evidence favoring classification as a retrovirus. $J$. Virol. 19: 1073-1079.

6. Cho, H. J. and Ingram, D.G. 1972. Antigen and antibody in Aleutian disease in mink. I. Precipitation reaction by agar-gel electrophoresis. J. Immunol. 108: 555-557.

7. Clabough, D.L. 1990. Equine infectious anemia: The clinical signs, transmission, and diagnostic procedures. Vet. Med. 85: 1007-1019.

8. Coffin, J.M. 1991. Nomenclature of virus. Arch. Virol. Supple. 2: 290-299.

9. Coggins, L. and Norcross, N.L. 1970. Immunodiffusion reaction in equine infectious anemia. Cornell Vet. 60: 330-335.

10. Crawford, T.B., McGuire, T.C., and Henson, J.B. 1971. Detection of equine infectious anemia virus in vitro by immunofluorescence. Arch. ges. Virusforsch. 34: 332-339.

11. Dmochowski, L.L. 1971. Review of the clinical implication of the virus-autoimmune response. Ame. J. Comp. Pathol. 56: 261-264.

12. Fujimiya, Y., Perryman, L.E., and Crawford, T.B. 1979. Leukocyte cytotoxicity in a persistent virus infection: presence of direct cytotoxicity but absence of antibody-dependent cellular cytotoxic- 
ity in horses infected with equine infectious anemia virus. Infect. Immun. 24: 628-636.

13. Gerencer, M., Valpotic, I., Jukic, B., Tomaskovic, M., and Basic, I. 1989. Qualitative analyses of cellular immune functions in equine infectious anemia show homology with AIDS. Arch. Virol. 104: 249-257.

14. Hanagata, T. and Akiyama, Y. 1971. Statistical investigation on light horses infected with equine infectious anemia in Japan. I. Statistical Investigation from 1964 to 1968. Jap. J. Vet. Sci. 33: 14-15 (Oral presentation. in Japanese).

15. Ishii, S. 1951. Diagnostic de l'anemie infectieuse du cheval au Japon. Bull. Off. Int. Epizoot. 36: 282-303.

16. Ishii, S. 1963. Equine infectious anemia or swamp fever. Adv. Vet. Sci. 8: 263-298.

17. Ishii, S., Nakamura, N., and Watanabe, S. 1937. Studies on EIA virus. I. Experimental studies on the distribution of the virus in various organs of horses affected with the disease-especially at afebrile stage. Jueki Chosasho Kenkyu Hokoku (Present title: Bull. Nat. Inst. Anim. Hlth) 17: 1-30 (In Japanese).

18. Ishii, S., Nobuto, K., and Tanaka, K. 1940. On the histo-pathological studies of infectious anemia in horses. On the detection of siderocytes in the blood ov vena jugularis and its clinical diagnosis value. Jap. J. Vet. Sci. 2: 531-557 (In Japanese. English summary.).

19. Ishii, S., Tanaka, K., and Sonoda, A. 1956. Diagnostic de l'anemia infectieuse des equides. Resultat d'experiences effectuees en 1954-1955. Bull. Off. Int. Epizoot. 45: 255-263.

20. Ishitani, R. 1970. Equine infectious anemia. Nat. Inst. Anim. Hlth Quart. 10 (Suppl.): 1-28.

21. Kemen, M.J.J. and Coggins, L. 1972. Equine infectious anemia: Transmission from infected mares to foals. J. Ame. Vet. Med. Assoc. 161: 496-499.

22. Kobayashi, K. 1961. Studies on the cultivation of equine infectious anemia virus in vitro. I. Serial cultivation of the virus in the culture of various horse tissue. Virus 11: 177-189 (In Japanese. English summary.).

23. Kobayashi, K. 1961. Studies on the cultivation of equine infectious anemia virus in vitro. II. Propagation of the virus in horse bone marrow cell culture. Virus 11: 189-201 (In Japanese. English summary.).

24. Kobayashi, K. 1961. Studies on the cultivation of equine infectious anemia virus in vitro. III. Propagation of the virus in horse leukocyte culture. Virus 11: 249-256 (In Japanese. English summary.).

25. Kobayashi, K. and Kono, Y. 1967. Propagation and titration of equine infectious anemia virus in horse leukocyte culture. Nat. Inst. Anim. Hlth
Quart. 7: 8-20.

26. Kobayashi, K. and Kono, Y. 1967. Serial passage of equine infectious anemia rirus in horse leukocyte culture. Nat. Inst. Anim. Hlth Quart. 7: 1-7.

27. Kono, Y. 1969. Viremia and immunological responses in horses infected with equine infectious anemia virus. Nat. Inst. Anim. Hlth Quart 9: 1-9.

28. Kono, Y. 1972. Recurrences of equine infectious anemia. Approaches to an understanding of the mechanisms. Proc. $3 r d$ Int. Conf. Equine Infect. Dis. 175-186.

29. Kono, Y. 1973. Recurrences of equine infectious anemia. Approaches to an understanding of the mechanisms. Proc. 3rd Int. Conf. Equine Infect. Dis. 175-186.

30. Kono, Y. 1988. Antigenic variation of equine infectious anemia virus as detected by virus neutralization. Arch. Virol. 98: 91-97.

31. Kono, Y., Fukunaga, Y., and Kobayashi, K. 1973. Excretion of equine infectious anemia virus from horses infected with the virus. Nat. Inst. Anim. Hlth Quart. 13: 182-186.

32. Kono, Y. and Kobayashi, K. 1964. Cytopathogenic Equine Orphan (CEO) virus in horse kidney cell culture. I. Isolation and properties. Nat. Inst. Anim. Hlth Quart. 4: 10-20.

33. Kono, Y. and Kobayashi, K. 1964. Cytopathogenic Equine Orphan (CEO) virus in horse kidney cell culture. II. Immunological studies of CEO virus. Nat. Inst. Anim. Hlth Quart. 4:21-27.

34. Kono, Y. and Kobayashi, K. 1966. Complement fixation test of equine infectious anemia. I. Specificity of the test. Nat. Inst. Anim. Hlth Quart. 6: 194-203.

35. Kono, Y. and Kobayashi, K. 1966. Complement fixation test of equine infectious anemia. II. Relationship between CF antibody response and the disease. Nat. Inst. Anim. Hlth Quart. 6: 204-207.

36. Kono, Y., Kobayashi, K., and Fukunaga, Y. 1970. Immunization of horses against equine infectious anemia (EIA) with an attenuated EIA virus. Nat. Inst. Anim. Hlth Quart. 10: 113-122.

37. Kono, Y., Kobayashi, K., and Fukunaga, Y. 1971. Serological comparison among various strains of equine infectious anemia virus. Arch. ges. Virusforsh. 34: 202-208.

38. Kono, Y., Kobayashi, K., and Fukunaga, Y. 1973. Antigenic drift of equine infectious anemia virus in chronically infected horses. Arch. ges. Virusforsch. 41: 1-10.

39. Kono, Y., Sentsui, H., and Murakami, Y. 1978. Lymphocyte responses to specific viral antigen and nonspecific mitogens in horses infected with equine infectious animia virus. Proc. 4 th int. Conf. Equine Infectious Diseases, 363-374.

40. Kono, Y. and Yokomizo, Y. 1968. Attempts to cultivate the equine infectious anemia virus in 
various types of cells. Nat. Inst. Anim. Hlth Quart. 8: $182-186$.

41. Kono, Y., Yoshino, T., and Fukunaga, Y. 1970. Growth characteristics of equine infectious anemia virus in horse leukocyte culture. Arch. ges. Virusforsh. 30: 252-256.

42. Kryukov, N.N., Yurov, K.P., and Sadukov, V.E. 1968. Propagation of equine infectious anemia virus in guinea-pg bone marrow cells. Byull. Vses. Inst. Eksp. Vet. 3-4 (Cited from Vet. Bull. 40, 192 (1970)).

43. Malmquist, W.A., Barnett, D., and Becvar, C.S. 1973. Production of equine infectious anemia antigen in a persistently infected cell line. Arch. ges Virusforsch. 42: 361-370.

44. Matheka, H.D., Coggins, L., Shively, J.N., and Norcross, N.L. 1976. Purification and characterization of equine infectious anemia virus. Arch. Virol. 51: 107-114.

45. McGuire, T.C. 1976. Suppression of synthesis of an IgG subclass in a persistent viral infectionequine infectious anemia. Immunology. 30: 17-24.

46. McGuire, T.C. 1977. Immunoglobulin G subclass [IgG and $\operatorname{IgG}(\mathrm{T})]$ interaction with the P26 group specific antigen of equine infectious anemia virus: immunodiffusion and complement-fixation reactions. Ame. J. Vet. Res. 38: 655-658.

47. McGuire, T.C., Crawford, T.B., and Henson, J.B. 1971. Immunofluorescent localization of equine infectious anemia virus in tissue. Am. J. Pathol. 62: 283-294.

48. McGuire, T.C., Henson, J.B., and Burger, D. 1969. Complement (C'3)-coated red blood cells following infection with the virus of equine infectious anemia. J. Immunol. 103: 293-299.

49. McGuire, T.C., Hoosier, G.L., and Henson, J.B. 1971. The complement-fixation reaction in equine infectious anemia: Demonstration of inhibition by $\operatorname{IgG}(\mathrm{T})$. J. Immunol. 107: 1738-1744.

50. McGuire, T.C., O'Rourke, K.I., and Cheevers, W.P. 1987. A review of antigenic variation by the equine infectious anemia virus. Contr. Microbiol. Immunol. 8: 77-89.

51. McGuire, T.C., Perryman, L. E., and Henson, J.B. 1970. Immunoglobulin composition of the hypergammaglobulinemia of equine infectious anemia. Fed. Proc. 435 (1072).

52. Nakajima, H. 1972. Physicochemical and biological characteristics of equine infectious anemia virus. Proc. 3rd int. Conf. Equine Infectious Diseases 162-174.

53. Nakajima, H. 1972. Immunodiffusion studies in equine infectious anemia and their evaluation for diagnosis. Proc. 3rd int. Conf. Equine Infectious Diseases 199-214.

54. Nakajima, H. 1974. Diagnosis of equine infectious anemia by immunodiffusion test. Jap. Agr. Res. Quart. 8: 47-53.
55. Nakajima, H. 1976. Equine infectious anemia virus-similar characteristics to RNA tumor virus. Chemistry and Biology 14: 48-50. (In Japanese).

56. Nakajima, H. 1976. Equine infectious anemia. Recent research on the virology, serology and diagnosis. Animal Health Status in Several Countries in the Region. 1976. IV.

57. Nakajima, H. 1977. Properties of equine infectious anemia virus. 25-30, In: Equine Infectious Anemia-Pathogenesis of the Disease and New Diagnostic Method-Nat. Inst. Anim. Hlth eds.) Nihon Jyuishikai, Tokyo (in Japanese).

58. Nakajima, H. 1977. Agar gel immunodiffusion test- A new diagnostic method- 93-156. ibid.

59. Nakajima, H. 1989. Equine infectious anemia virus. New Veterinary Microbiology (Yokendo) 852-859 (In Japanese).

60. Nakajima, H., Fukunaga, Y., and Ushimi, C. 1974. Titration of precipitating antibody in equine infectious anemia. Nat. Inst. Anim. Hlth Quart. 14: 1-8.

61. Nakajima, H., Kobayashi, K., Kono, Y., and Ushimi, C. Kobayashi, K., Kono, Y., and Ushimi, C. 1972. Field application of immunodiffusion and complement fixation tests for diagnosis of equine infectious anemia. Nat. Inst. Anim. Hlth Quart. 12: 183-187.

62. Nakajima, H., Kono, Y., and Ushimi, C. 1971. Characterization of precipitating antibody in equine infectious anemia. J. Immunol. 107: 889-894.

63. Nakajima, H., Mizuno, Y., Yasuda, K., and Ushimi, C. 1973. Physicochemical studies of equine infectious anemia virus. V. Effect of ultraviolet irradiation on virus infectivity. Arch. ges. Virusforsch. 41: 135-137.

64. Nakajima, H., Norcross, N.L., and Coggins, L. 1972. Demonstration of antigenic identity between purified equine infectious anemia virus and an antigen extracted from infected horse spleen. Inf. Immun. 6: 416-417.

65. Nakajima, H. and Obara, J. 1964. Ether susceptibility of equine infectious anemia virus. Nat. Inst. Anim. Hlth Quart. 4: 129-134.

66. Nakajima, H., Sugiura, T., and Ushimi, C. 1976. Demonstration of ribonucleic acid-dependent deoxyribonucleic acid polymerase activity associated with equine infectious anemia virus. 4 th. Int. Conf. Equine Infectious Diseases; Equine Infectious Anemia Workshop 3-9.

67. Nakajima, H., Sugiura, T., and Ushimi, C. 1978. Immunodiffusion test for the diagnosis of equine infectious anemia. Proc. 4th Int. Conf. Equine Infectious Diseases 339-349.

68. Nakajima, H., Tajima, M., Tanaka, S., and Ushimi, C. 1969. Physicochemical studies of equine infectious anemia virus. III. Purification and electron microscopic observation of the virus. 
Arch. ges. Virusforsh. 28: 348-360.

69. Nakajima, H., Tanaka, S., and Ushimi, C. 1968. Fractionation of equine infectious anemia virus by diethylaminoethyl cellulose chromatography and sucrose density gradient centrifugation. Nat. Inst. Anim. Hlth Quart. 8: 57-63.

70. Nakajima, H., Tanaka, S., and Ushimi, C. 1969. Physicochemical studies of equine infectious anemia virus. I. Buoyant density of the virus. Arch. ges. Virusforsch. 26: 389-394.

71. Nakajima, H., Tanaka, S., and Ushimi, C. 1969. Physicochemical studies of equine infectious anemia virus. II. Sensitivity of the virus to trypsin. Ach. ges. Virusforsh. 26: 395-397.

72. Nakajima, H., Tanaka, S., and Ushimi, C. 1970. Physicochemical studies of equine infectious anemia virus. IV. Determination of the nucleic acid type in the virus. Arch. ges. Virusforsh. 31: 273-280.

73. Nakajima, H. and Ushimi, C. 1971. Immunodiffusion studies of purified equine infectious anemia virus. Inf. Immun. 3: 373-377.

74. Nakajima, H. and Ushimi, C. 1972. Detection of precipitating antibody in equine infectious anemia by concentrated virus antigen. Nat. Inst. Anim. Hlth Quart. 12: 47-53.

75. Nakajima, H., Ushimi, C., Fukunaga, Y., and Hirasawa, K. 1973. Preparation of equine infectious anemia virus antigen for immunodiffusion test. Arch. ges. Virusforsch. 42: 339-345.

76. Nakajima, H., Yoshino, T., and Ushimi, C. 1974. Equine infectious anemia virus from infected horse serum. Infect. Immun. 10: 667-668.

77. Nakamura, J., Kuroda, S., Ueda, S., and Samejima, T. 1974. Studies on complement-fixation reaction in equine infectious anemia. I. Development and activities of complement-fixing and complement fixation-inhibiting antibodies. Jap. J. Microbiol. 18: 385-395.

78. Newman, M.J., Issel, C.J., Truax, R.E., Powell, M.D., Horohov, D.W., and Montelaro, R.C. 1991. Transient suppression of equine immune responses by equine infectious anemia virus (EIAV). Virology 184: 55-66

79. Nishimura, M. and Nakajima, H. 1984. Structural proteins of equine infectious anemia virus and their antigenic activity. Ame. J. Vet. Res. 45: 5-10.

80. Obara, J. and Nakajima, H. 1961. Iron metabolism in equine infectious anemia. V. Erythrocyte destruction. Nat. Inst. Anim. Hlth Quart. 1: 32-35.

81. Obara, J. and Nakajima, H. 1961. Iron metabolism in equine infectious anemia. VI. Organ uptake of plasma-bound iron-59. Nat. Inst. Anim. Hlth Quart. 1: 36-40.

82. Obara, J. and Nakajima, H. 1961. Kinetics of iron metabolism in equine infectious anemia. Jap. J. Vet. Sci. 23: 247-253.

83. Obara, J. and Nakajima, H. 1961. Life span of
$51 \mathrm{Cr}$-labeled erythrocytes in equine infectious anemia. Jap. J. Vet. Sci. 23: 207-210 (In Japanese. English summary.).

84. Obara, J., Nakajima, H., and Yamamoto, H. 1958. Iron metabolism in equine infectious anemia. II. Storage iron. Bull. Nat. Inst. Anim. Hlth 35: 139-147 (In Japanese. English summary.).

85. Obara, J., Sonoda, A., and Nakajima, H. 1962. Determination of DFP32-labeled erythrocyte lifespan and plasma cholinesterase turnover rate in equine infectious anemia. Nat. Inst. Anim. Hlth Quart. 2: 229-236.

86. Oki, Y. 1957. Biochemical studies on the hemosiderosis in horses. Jap. J. Vet. Sci. 19: 53-60 (In Japanese. English summary.).

87. Oki, Y. 1958. Pathologic physiological studies on free ferritin in the blood of anemia infected horse. I. The proof for the identification method of free ferritin in the serum by the complement fixation test. Jap. J. Vet. Sci. 20: 129-137 (In Japanese. English summary.).

88. Oki, Y. and Fujita, J. 1959. Pathologic physiological studies on free ferritin in the blood of anemia infected horse. II. On the prosperity and decline of free ferritin in the serum of the jugular vein. Jap. J. Vet. Sci. 21: 71-83 (In Japanese. English summary.).

89. Oki, Y. 1959. Pathologic physiological studies on free ferritin in the blood of anemia infected horse. III. On the role of circulating ferritin that has an influence on the clinical symptoms. Jap. J. Vet. Sci. 21: 241-256.

90. Oki, Y. and Inoue, T. 1966. Immunological studies in equine infectious anemia. I. On the pathologic autohemagglutinin and heterogenetic hemagglutinin. Jap. J. Vet. Sci. 28: 355 (In Japanese. English summary).

91. Oki, Y. and Miura, K. 1970. Characteristics and roles of red cell auto-antibodies in equine infectious anemia. Jap. J. Vet. Sci. 32: 217-226 (In Japanese. English summary).

92. Oldstone, M.B.A. and Dixon, F.J. 1971. Immune complex disease in chronic viral infection. J. Exp. Med. 134: 32-40.

93. Perryman, L.E., Banks, K.L., and McGuire, T.C. 1975. Lymphocyte abnormalities in Aleutian disease virus infection of mink: decreased $\mathrm{T}$ lymphocyte responses and increased $\mathrm{B}$ lymphocyte levels in persistent viral infection. J. Immunol. 115: 22-27.

94. Perryman, L.E., McGuire, T.C., Banks, K.L., and Henson, J.B. 1971. Decreased C3 levels in a chronic virus infection: equine infectious anemia. J. Immun. 106: 1074-1078.

95. Petrovic, D., Lulic, V., and Zeleznik, Z. 1972. A contribution to the diagnostics of equine infectious anemia. Viral replication in a line culture of human fetal lung fibroblasts Wi-38. Vet. Arhiv. 42: 
113-120.

96. Porter, D.D., Dixon, F.J., and Larsen, A.E. 1965. Metabolism and function of gamma globulin in Aleutian disease of mink. J. Exp. Med. 121: 889-900.

97. Sentsui, H. and Kono, Y. 1976. Hemagglutination by equine infectious anemia virus. Infec. Immunity 14: 325-331.

98. Sentsui, H. and Kono, Y. 1978. Preparation of hemagglutinating antigen of equine infectious anemia virus from infected equine leukocyte culture. Nat. Inst. Anim. Hlth Quart. 18: 39-40.

99. Sentsui, H. and Kono, Y. 1981. Hemagglutination by several strains of equine infectious anemia virus. Arch. Virol. 67: 75-84.

100. Shen, D.T., Gorham, J.R., and McGuire, T.C. 1984. Enzyme-linked immunosorbent assay for detection of equine infectious anemia antibody to purified p26 viral protein. Ame. J. Vet. Res. 45: 1542-1543.

101. Sugiura, T. 1977. Immunological reaction in infected horses. 30-35, In: Equine Infectious Anemia-Pathogenesis of the Disease and New Diagnostic Method-Nat. Inst. Anim. Hlth eds.) Nihon Jyuishikai, Tokyo (in Japanese).

102. Sugiura, T., Matsumura, T., and Fukunaga, Y. 1986. Diagnosis of equine infectious anemia by enzyme-linked immunosorbent assay with viral antigen purified by affinity chromatography. Bull. Equine Res. Inst. 23: 42-48.

103. Sugiura, T. and Nakajima, H. 1977. Purification of equine infectious anemia virus antigen by affinity chromatography. J. Clin. Microbiol. 5: 635-639.

104. Sugiura, T. and Nakajima, H. 1982. Indirect hemagglutination test in equine infectious anemia. Can. J. Comp. Med. 46: 60-64.

105. Suzuki, T., Ueda, S., and Samejima, T. 1982. Enzyme-linked immunosorbent assay for diagnosis of equine infectious anemia. Vet. Microbiol. 7: 307-315.

106. Tajima, M., Nakajima, H., and Ito, Y. 1969. Electron microscopy of equine infectious anemia virus. J. Virology. 4: 521-527.

107. Tanaka, K., Hirasawa, K., and Sakaki, K. 1964. Relationships of serum protein fractions at the febrile stage of equine infectious anemia and activity of the virus. Rep. Res. Equine Infect. Anemia. 2: 108-114.

108. Tanaka, K. and Sakaki, K. 1962. Neutralization test on serum from horses infected with the virus of equine infectious anemia. Nat. Inst. Anim. Hlth Quart. 2: 128-139.

109. Tokui, T., Hirato, K., and Miura, S. 1968. Studies of the equine infectious anemia virus in tissue cultures. IV. The in vitro neutralization test. Rep. Res. Equine Infect. Anemia 3: 12-20 (In Japanese).

110. Ueda, S. 1975. Studies on complement-fixation reaction in equine infectious anemia. II. Identification of complement-fixing inhibitors. Jap. J. Microbiol. 19: 173-180.

111. Ushimi, C. 1978. Immunoglobulins related to complement-fixation inhibition antibody and precipitating antibody in equine infectious anemia. Proc. 4th Int. Conf. Infectious Diseases 381-388.

112. Ushimi, C., Henson, J.B., and Gorham, J.R. 1972. Study of the one-step growth curve of equine infectious anemia virus by immunofluorescence. Inf. Immun. 5: 890-895.

113. Ushimi, C., Nakajima, H., and Tanaka, S. 1970. Demonstration of equine infectious anemia viral antigen by immunofluorescence. Nat. Inst. Anim. Hlth Quart. 10: 90-91.

114. Vallèe, H. and Carrè, H. 1904. Sur la nature infectiruse de l'anemie du cheval. Hebd. Seanc. Acad. Sci. Paris 139: 331-333.

115. Winston, S., Fiscus, S., Hesterberg, L., Matsushita, T., Mildbrand, M., Porter, J., and Teramoto, Y. 1987. Rapid detection of viral-specific antibodies by enzyme-linked immunosorbent assay (ELISA). Vet. Immunol. Immunopathol. 17: 453-464.

116. Yamamoto, H. and Konno, S. 1967. Pathological studies on bone marrow in equine infectious anemia. I. Macroscopical findings on whole longitudinal sections of bone marrow. Nat. Inst. Anim. Hlth Quart. 7: 40-53.

117. Yamamoto, H., Yoshino, Y., Nakajima, H., and Ishitani, R. 1972. Relationship between histopathological and serological findings in field cases of equine infectious anemia. Nat. Inst. Anim. Hlth Quart. 12: 193-200. 